\title{
A Nonisolated Three-Port DC-DC Converter with Continuous Input and Output Currents Based on Cuk Topology for PV/Fuel Cell Applications
}

\author{
Balaji Chandrasekar ${ }^{1, *(\mathbb{D})}$, Chellammal Nallaperumal ${ }^{1}$ and Subranshu Sekhar Dash ${ }^{2}$ \\ 1 Department of Electrical and Electronics Engineering, SRM IST, Kattankulathur, Chennai, \\ Tamilnadu PIN-603203, India; chellavenkat09@gmail.com \\ 2 Department of Electrical and Electronics Engineering, Government College of Engineering, Keonjhar, \\ Odisha PIN-758002, India; subhransudash_fee@gcekjr.ac.in \\ * Correspondence: balaji2work@gmail.com; Tel.: +91-9176056974
}

Received: 14 January 2019; Accepted: 10 February 2019; Published: 15 February 2019

\begin{abstract}
A nonisolated three-port DC-DC converter based on Cuk topology (NI-TPC) to handle the renewable sources (RS) is proposed in this paper. This converter includes two unidirectional input ports accommodating both a fuel cell (FC) and photovoltaic (PV) cell; and one output port with DC load. Due to the inductors at all the ports, it claims the advantage of continuous input and output currents. Additionally, it uses less number of switches, diodes and inductors compared with conventional ' $n-1$ ' separate Cuk converters. Synthesis procedure for a generalized n-port DC-DC structure is explained. The derivation law based on conventional Cuk converter, operating principle, design calculation, and analysis are presented in detail, and then the analysis is validated through simulation and a 100W prototype, verifying the performance of the proposed NI-TPC converter.
\end{abstract}

Keywords: DC-DC; Nonisolated; Three-port; Cuk; PV/Fuel cell; Continuous current

\section{Introduction}

Fast and society-threatening global warming and health hazards due to the combustion of fossil fuels have triggered the research and development of more efficient and cleaner renewable sources (RS) namely solar, wind, fuel cell etc. Many DC-DC converters with a single inductor, for example, buck and boost converters and two inductor converters, such as Sepic, Cuk, and zeta converters, have been used to connect RS and load [1,2]. However, the stochastic and time-varying characteristics of these sources and unpredictable demand at load side necessitate the backup source for continuous power flow to the load. This condition forces the system to have at least two input ports; one for RS and another for a backup source such as fuel cell/wind/battery.

In the recent past, new converter topologies called multiport converters (MPC) have been proposed to integrate these RS, which ensure the continuous power flow to the load. The structure of conventional and MPC system is shown in Figure 1. The MPCs enhance the utilization of power sources based on their V-I characteristics, availability and cost [3]. Multiport converters (MPC) which claim the advantage of component sharing are acknowledged as one of the promising topologies to integrate the RS to cater the future energy generation requirements. Moreover, compact structure and lesser conversion stages are the reasons to adopt MPC for numerous applications such as hybrid power system [4], renewable energy integration [5], hybrid vehicles [6], aerospace applications, and uninterrupted power supplies. This MPC, in particular, the three-port converter (TPC) can be divided into three groups: (1) the isolated DC-DC converter; (2) semi-isolated DC-DC converter; and (3) nonisolated converter topologies. The isolated TPC uses a transformer with a high-frequency 
to provide magnetic coupling and electrical isolation between the source and load [6-8]; partially isolated converters use a common DC bus along with magnetic coupling [9]. A nonisolated TPC uses common DC bus and finds applications where the isolation is not needed between the ports [10-12].

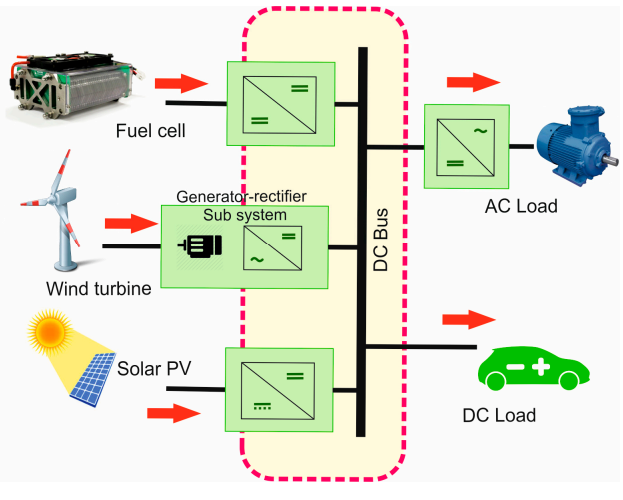

(a)

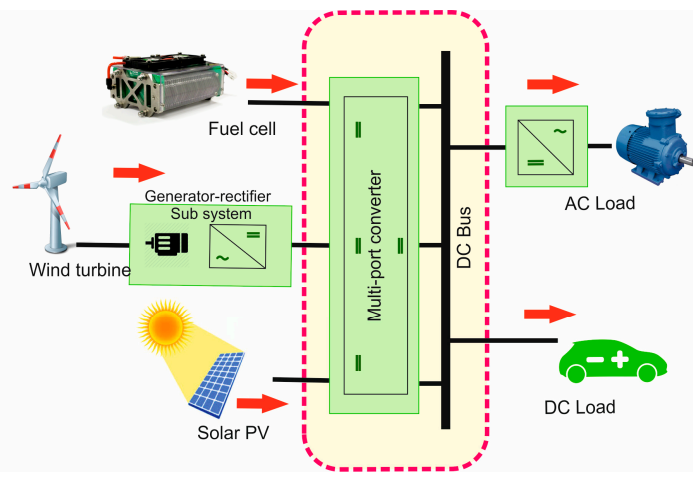

(b)

Figure 1. (a) Structure of the conventional system, (b) Proposed multiport converter (MPC) system.

TPCs can be configured in two topologies based on the nature of the input sources: series and parallel. In the series topology, the output voltage regulation becomes challenging if one of the input sources reduces (e.g., in PV shading condition) [13]. Assumptions and conditions to design the converters with multiple input-single output (MISO) from the conventional single input-single output (SISO) structures are explained [14]. The systematic way of synthesizing MISO converters is detailed in Reference [15]. Topology generation methods and principles for developing a family of NI-TPC are proposed [16]. These TPCs are developed by introducing a SISO model in an existing dual input or two output converters. In Reference [17], an approach to systematically derive MPCs with DC link inductor concept and with two input and two output converters is proposed. This procedure has developed numerous TPC topologies. A novel nonisolated TPC with single inductor is proposed for RS [18]. This converter features the integration and control of bidirectional load, compactness, single stage power conversion between any two ports, and seven possible operational modes. The design of a NI-TPC using one switch for a standalone PV power system integrating energy storage is proposed in Reference [19]. A synchronous switch with a pair of diodes has been utilized instead of two individual switches. However, the converters in both the stages must operate synchronously. The inherent buck-boost characteristics of the Cuk converter provide flexibility for standalone and grid-tied applications when the output voltage required is more or less than the input voltage. Continuous current at the input and output ports and the identical switching voltage waveforms appearing across the inductors are the salient features of the Cuk converter [20]. New topologies with high voltage ratio have been proposed using Cuk converter in Reference [21] for renewable power applications. In Reference [9], A TPC is presented by integrating a Cuk converter with bidirectional power flow and a full-bridge (FB) rectifier circuit for renewable energy applications. It used a transformer with high frequency. This converter consists of two nonisolated and one isolated ports. A nonisolated DC-DC TPC using integrated boost-cuk topology with high voltage gain is proposed [22]. An isolated TPC depending on Cuk converter is presented in Reference [23] by incorporating the inductor and transformers on a single core. Three winding transformer used in the above converter increases the size. Moreover, it uses more number of switches. The three-port Cuk converter to solve the zero-ripple problem is presented by designing a single integrated magnetic core having all the magnetics on it [24]. Methods based on circuit theory and the structure of the core are used to analyze the ripples. However, these converters are the isolated type and use bulky transformers and inductors. In Reference [25], a DC-DC converter combining a SEPIC and Cuk converter is proposed for bipolar DC microgrid 
applications. A single switch shared by both converters is an added advantage. However, the number of power components is greater.

However, the TPCs mentioned above fail to provide a high voltage conversion ratio and continuous current at all the ports.

The outstanding features of the proposed converter are

- Both the input ports share common output inductor, hence minimizing the component count.

- Continuous current with less ripple in all the ports (the input and output ports).

- Delivered power from each input can be independently controlled

- Buck-boost output voltages can be obtained.

To the best of the author's knowledge, the design and development of NI-TPC converter has not been reported earlier in literature. In this paper, the design, development, and extensive analysis of the proposed converter have been carried out to validate the performance of the converter.

Generally, the energy flow control modes and circuit analysis procedure are common sense and well discussed in many other papers [4,26-31]. However, the DC-DC structure of the Cuk-Cuk converter used for the system that integrates the input ports (1 and 2) to DC Bus (Port 3) is new, which increases the novelty of the paper.

\section{Proposed Converter Structure}

\subsection{Synthesis of the NI-TPC Converter}

This section presents the illustration of synthesizing the proposed NI-TPC converter from a classical Cuk converter. Based on the fundamentals, the structure of the classical Cuk converter can be deduced to the input section, output section, and an energy buffer section that connects both, as shown in Figure 2. The capacitor acts as a voltage buffer and transfers energy from input to output section without consuming any energy. The input with voltage buffer and output sections are separated and connected as represented in Figure 2 to form the generalized n-port structure.

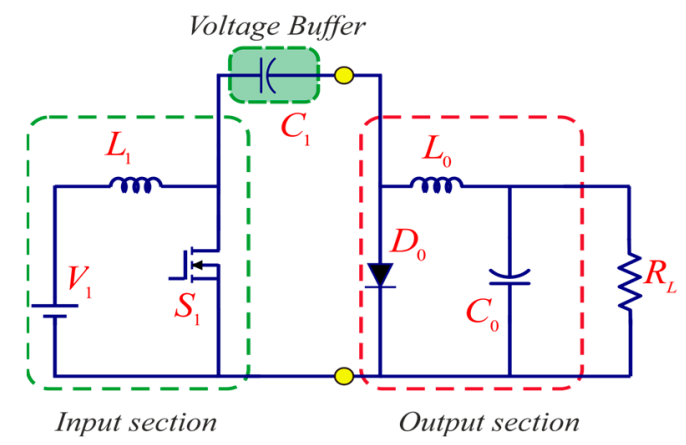

Figure 2. Structure of classical Cuk converter.

The resulting structure of the proposed ' $n$ ' port converter consists of ' $n-1$ ' input sources, ' $n$ ' inductors, ' $n$ ' capacitors, ' $n-1$ ' switches and a single diode is presented in Figure 3. Table 1 gives a comparison of the circuit elements used in the proposed and conventional structures.

A three-port converter with two input ports and a load port is taken for better understanding as shown in Figure 4. One can understand that it is based on the integration of two classical Cuk converters. The proposed TPC consists of three inductors $\left(\mathrm{L}_{1}, \mathrm{~L}_{2}\right.$, and $\left.\mathrm{L}_{0}\right)$, three capacitors $\left(\mathrm{C}_{1}, \mathrm{C}_{2}\right.$, and $\left.C_{0}\right)$, two switches $\left(S_{1}-S_{2}\right)$, and one diode $\left(D_{0}\right)$. Power sources $V_{1}$ and $V_{2}$ are connected to the unidirectional input ports. 


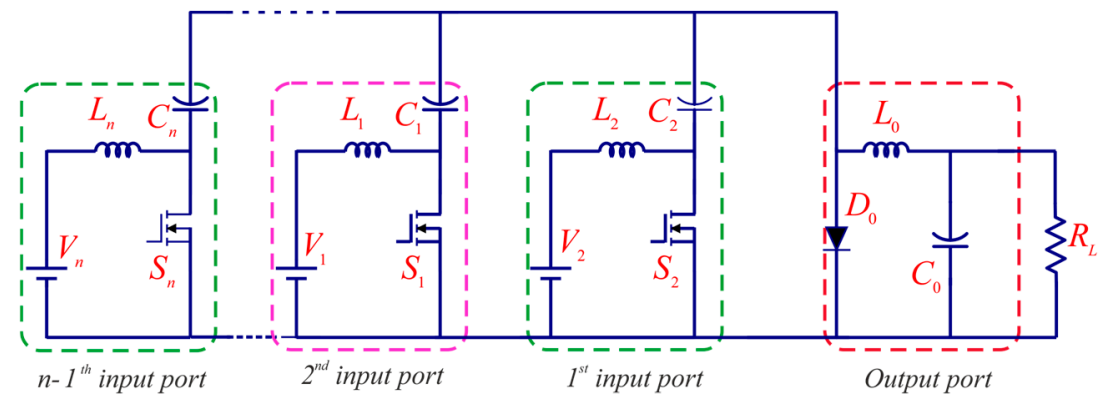

Figure 3. Generalized structure of the proposed 'n' port converter.

Table 1. Comparison of circuit elements.

\begin{tabular}{ccc}
\hline Circuit Elements & Proposed n-Port Cuk-Cuk Converter & (n-1) Individual Cuk Converters \\
\hline Inductors & $\mathrm{n}$ & $2(\mathrm{n}-1)$ \\
Capacitors & $\mathrm{n}$ & $2(\mathrm{n}-1)$ \\
Switch & $\mathrm{n}-1$ & $\mathrm{n}$ \\
Diode & 1 & $2(\mathrm{n}-1)$ \\
\hline
\end{tabular}

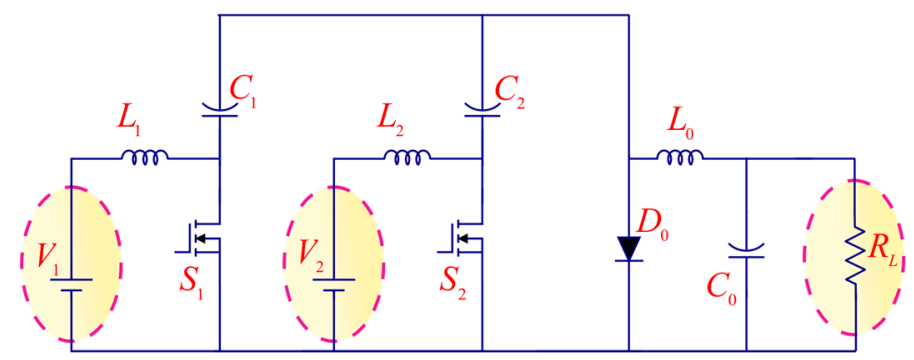

Figure 4. Proposed three-port converter.

\subsection{Operating Principles}

Based on the availability of power sources, the proposed TPC can function in two different modes: the SISO and dual input single output (DISO) modes. Either of the input ports can cater to load in the absence of the other in SISO mode. In DISO mode, both sources contribute power to load when the primary power source is insufficient to meet the load demand. The proposed NI-TPC converter can function in all these modes through appropriate control.

\subsubsection{SISO Mode}

Figure 5a shows the Equivalent circuit when operating in SISO mode. The equivalent circuits of state 1 and state 2 are shown in Figure $5 b, c$, respectively. The waveforms are not shown since it is similar to the classical Cuk converter.

\section{State 1}

In this mode, switch $S_{1}$ is $O N$, but the diode is not conducting. Voltage source $V_{1}$ magnetizes the inductor $\mathrm{L}_{1}$. The positive voltage on the inductor makes the inductor current $\mathrm{i}_{\mathrm{L} 1}$ to increase linearly. The capacitor $C_{1}$ is assumed precharged and discharging its energy to the load through the inductor $\mathrm{L}_{0}$. Hence, the inductor current $\mathrm{i}_{\mathrm{L} 2}$ increases linearly. In addition, it charges the output capacitor $\mathrm{C}_{0}$. Various currents and voltages can be expressed by (1). 


$$
\left.\begin{array}{l}
V_{L 1}=V_{1} \\
V_{L 0}=V_{C 1}-V_{C 0} \\
i_{C 1}=i_{L 0} \\
i_{C 0}=i_{L 0}-i_{0}
\end{array}\right\}
$$

State 2

In this state, switch $S_{1}$ is OFF while the diode conducts and freewheels. The voltage source $V_{1}$ together with the energy stored in the inductor $L_{1}$, charge the capacitor $C_{1}$ through diode $D_{0}$. The current in the inductor $\mathrm{i}_{\mathrm{L} 1}$ decreases linearly. The output inductor $\mathrm{L}_{0}$ is demagnetized and its energy flows to the load through diode $\mathrm{D}_{0}$. Equation (2) is valid in this mode:

$$
\left.\begin{array}{l}
V_{L 1}=V_{1}-V_{C 1} \\
V_{L 0}=-V_{C 0} \\
i_{C 1}=i_{L 1} \\
i_{C 0}=i_{L 0}-i_{0}
\end{array}\right\}
$$

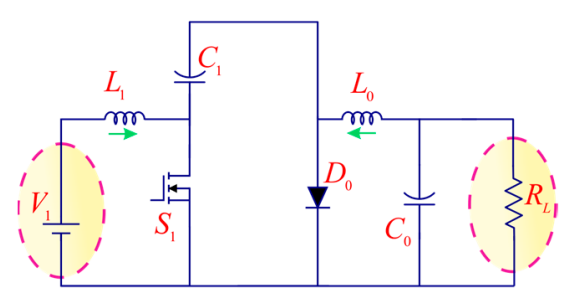

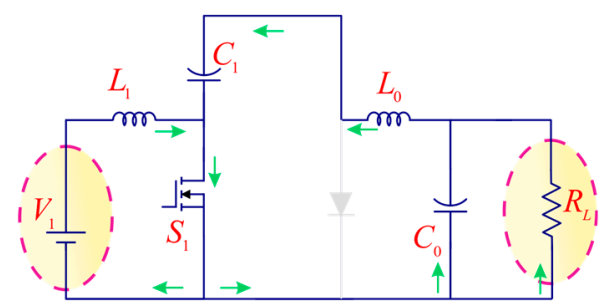

(b) (a)

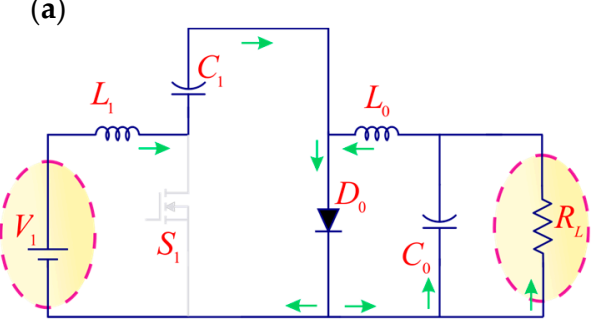

(c)

Figure 5. (a) Single input-single output (SISO) mode of the proposed converter: (b) State 1 and (c) State 2 .

\subsubsection{DISO Mode}

Better utilization of power sources needs a suitable control technique to achieve the regulated output power. The appropriate switching pattern in various modes depends on the time multiplexing of switching signals.

Selection of switching sequence can be done in many ways based on whether power is catered individually or simultaneously. A left-aligned switching pattern as shown in Figure 6 has been chosen in this work for analysis of the proposed converter. 


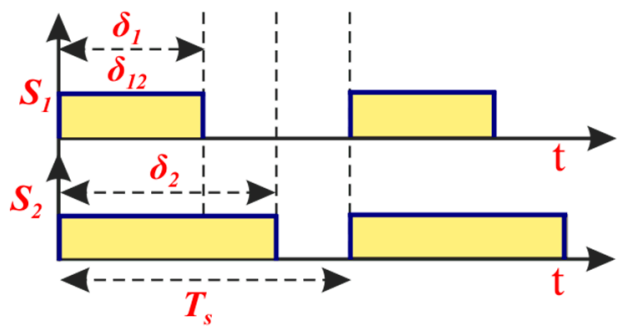

Figure 6. Left-aligned switching pattern.

State 1

During this state, both switches $\mathrm{S}_{1}$ and $\mathrm{S}_{2}$ are $\mathrm{ON}$, but the diode remains nonconducting. The voltage sources $V_{1}$ and $V_{2}$ magnetize the inductors $L_{1}$ and $L_{2}$ respectively. The positive voltage on the inductors makes the inductor currents increase linearly. Capacitors $C_{1}$ and $C_{2}$ are assumed precharged and to be discharging energy. The load is catered by the capacitors discharge through the inductor $\mathrm{L}_{0}$. The corresponding equivalent circuit is illustrated in Figure 7a. The corresponding equations have been presented in (4).

$$
\left.\begin{array}{l}
V_{L 1}=V_{1}, V_{L 2}=V_{2} \\
V_{L 0}=V_{0}-V_{C 1} \\
i_{C 1}+i_{C 2}=i_{L 0} \\
i_{C 0}=i_{L 0}-i_{0}
\end{array}\right\}
$$

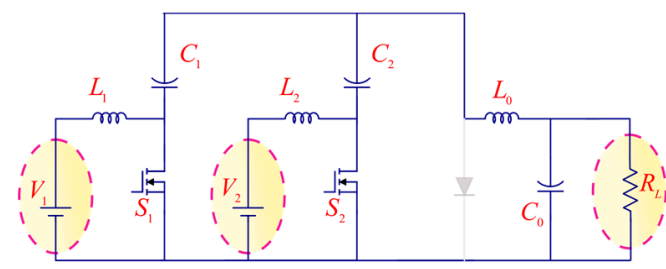

(a)

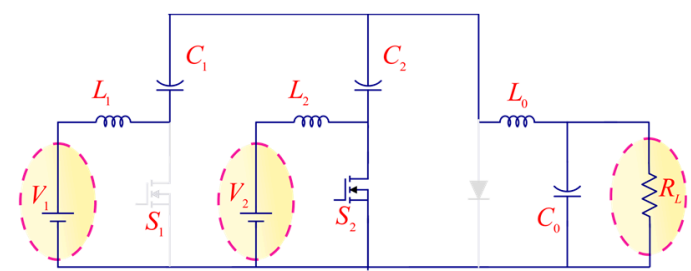

(b)

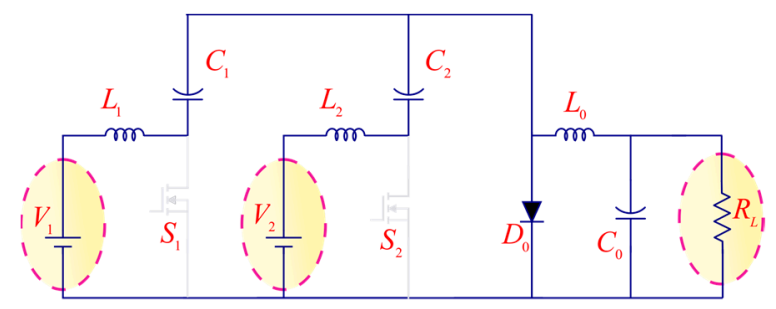

(c)

Figure 7. Equivalent circuits: (a) State 1, (b) State 2, and (c) State 3.

State 2

In this interval, switch $S_{1}$ is OFF and switch $S_{2}$ is $\mathrm{ON}$, but the diode stays nonconducting due to the voltage across capacitor $C_{2}$. The voltage source $V_{1}$ together with the energy stored in the inductor $\mathrm{L}_{1}$, charges the capacitor $\mathrm{C}_{1} . \mathrm{V}_{2}$ continues to discharge and magnetize the inductor $\mathrm{L}_{2}$. Due to the positive and constant voltage on inductor $L_{2}$, its current raises linearly. The capacitor $C_{2}$ continues to discharge as in Mode 1 , and the load is catered by it through the inductor $\mathrm{L}_{0}$. The corresponding equivalent circuit is presented in Figure 7b. Equation (5) is derived for this mode. 


$$
\left.\begin{array}{l}
V_{L 1}=V_{1}-V_{C 1}+V_{C 2} \\
V_{L 2}=V_{2}, V_{L 0}=V_{0}-V_{C 2} \\
i_{C 1}=i_{L 1}, i_{C 2}=i_{L 0}-i_{C 1} \\
i_{C 0}=i_{L 0}-i_{0}
\end{array}\right\}
$$

State 3

In this state, both switches $S_{1}$ and $S_{2}$ are OFF while the diode conducts and freewheels. The voltage sources $V_{1}$ and $V_{2}$ together with the energy stored in the inductors $L_{1}$ and $L_{2}$, charge capacitors $C_{1}$ and $C_{2}$ respectively. The current in the inductors $i_{L 1}$ and $i_{L 2}$ decreases linearly. The output inductor $L_{0}$ discharges and the load is catered by it through the Diode $\mathrm{D}_{0}$. The equivalent circuit of this state is illustrated in Figure 7c. Various currents and voltages can be expressed as in (6).

$$
\left.\begin{array}{l}
V_{L 1}=V_{1}-V_{C 1} \\
V_{L 2}=V_{2}-V_{C 2}, V_{L 0}=V_{0} \\
i_{C 1}=i_{L 1}, i_{C 2}=i_{L 2} \\
i_{C 0}=i_{L 0}-i_{0}
\end{array}\right\}
$$

Ideal operating conditions with Steady state and continuous conduction mode (CCM) is assumed to derive the expressions of the output voltage and voltage gain.

\section{Modeling and Analysis of the Converter}

The derivation of various parameters and modeling of the proposed NI-TPC converter are presented in this section.

\subsection{Voltage Gain}

The analytical expression for the output voltage has been obtained by applying volt second balance theory on inductors.

$$
\begin{gathered}
V_{1}=V_{c 1}\left(1-\delta_{1}\right)-V_{c 2}\left(\delta_{2}-\delta_{1}\right) \\
V_{c 2}=\frac{V_{2}}{\left(1-\delta_{2}\right)} \\
V_{0}=\delta_{1} V_{c 1}+\delta_{2} V_{c 2}
\end{gathered}
$$

The expression of the output voltage can be derived from Equations (7)-(9). The voltage equation in terms of duty cycles is

$$
V_{0}=\frac{\delta_{1}}{\left(1-\delta_{1}\right)} V_{1}+\frac{\delta_{2}\left(\delta_{2}-\delta_{1}\right)}{\left(1-\delta_{1}\right)\left(1-\delta_{2}\right)} V_{2}=G_{V 1} \cdot V_{1}+G_{V 2} \cdot V_{2}
$$

From (10), one can understand that the proposed converter operating in DISO mode has the same voltage gain compared with classical Cuk converter, which is plotted in Figure 8. Considering $\mathrm{V}_{1}=\mathrm{V}_{2}=\mathrm{V}$, the output voltage of the proposed converter is presented in (11). Selecting the same duty ratio for both the switches leads to the output voltage equal to the one in classical Cuk converter as derived in (12). The voltage gain for an n-port DC-DC Cuk-Cuk converter with the proposed topology can be derived as in (13).

$$
V_{0}=\frac{\delta_{1}}{\left(1-\delta_{1}\right)} V_{1}+\frac{\delta_{2}\left(\delta_{2}-\delta_{1}\right)}{\left(1-\delta_{1}\right)\left(1-\delta_{2}\right)} V_{2}=G_{V 1} \cdot V_{1}+G_{V 2} \cdot V_{2}
$$

Taking $\delta_{1}=\delta_{2}=\delta$

$$
V_{0}=\frac{\delta}{1-\delta} V
$$


For an n-port converter,

$$
V_{0}=\left[\frac{\delta_{1}}{1-\delta_{1}}+\sum_{i=2}^{n} \frac{\delta_{i}\left(\delta_{i}-\delta_{1}\right)}{\left(1-\delta_{1}\right)\left(1-\delta_{i}\right)}\right] V_{i}
$$

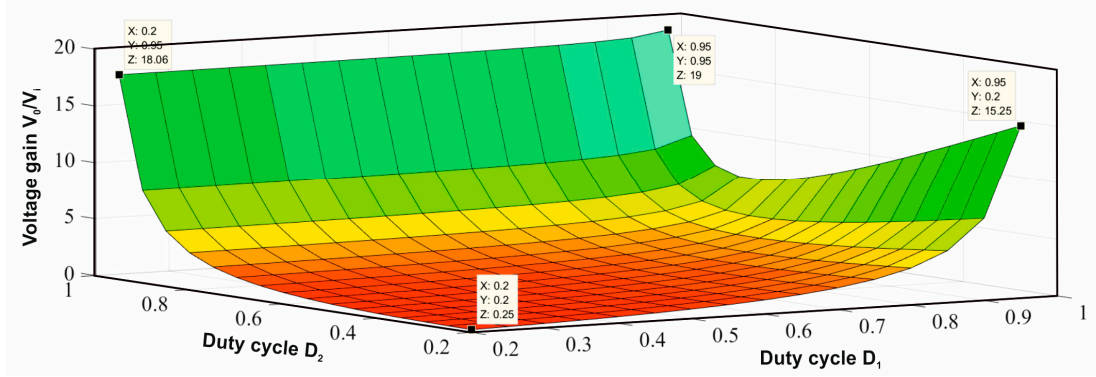

Figure 8. Voltage gain Vs Duty cycle of NI-TPC converter.

Applying the charge-sec balance principle on capacitors, the following equations are obtained.

$$
\begin{gathered}
\left\langle I_{C 1}\right\rangle=C_{1} \frac{d V_{1}}{d t}=\frac{i_{L 0}}{d t} \delta_{1}+i_{L 1} \delta_{e}+i_{L 1} \delta_{o f f} \\
i_{L 1}=\frac{\delta_{1}}{2\left(\delta_{1}-1\right)} i_{L 0} \\
\left\langle I_{C 2}\right\rangle=C_{2} \frac{d V_{2}}{d t}=\frac{i_{L 0}}{2} \delta_{1}+\left(i_{L 0}-i_{L 1}\right) \delta_{e}+i_{L 2} \delta_{o f f} \\
i_{L 2}=\left(\frac{\delta_{1} \delta_{2}}{2\left(\delta_{1}-1\right)}-\frac{\delta_{1}^{2}}{2\left(\delta_{1}-1\right)}-\delta_{2}+\frac{\delta_{1}}{2}\right) \frac{i_{L 0}}{\left(1-\delta_{2}\right)}
\end{gathered}
$$

\subsection{Current Ripples of Inductors}

Current ripples and inductor volt-second balance (IVSB) principle are used to design inductors. The inductor current ripple equations are modified to obtain equations for inductor values (16)-(18).

$$
\left.\begin{array}{c}
\Delta i_{L 1}=\frac{V_{1} \delta_{1} T_{S}}{2 L_{1}}=\frac{V_{1} \delta_{1}}{2 L_{1} f_{S}} \\
L_{1}=\frac{V_{1} \delta_{1}}{2 \Delta i_{L 1} f_{S}}
\end{array}\right\}
$$

The values of the inductors can be found, if output voltage, source voltages, desired ripples, switching frequency and duty cycle are known.

\subsection{Voltage Ripples of Capacitors}

Voltage ripples and the capacitor charge-second balance (CCSB) principle are used to design capacitors. The voltage ripple equations are modified to obtain equations for capacitor values (19)-(21).

$$
\left.\begin{array}{l}
\Delta V_{1}=\frac{\left(1-\delta_{1}\right) T_{S}}{C_{1}} \frac{2\left(\delta_{1}-1\right)}{\delta_{1} R} V_{0} \\
C_{1}=\frac{\left(1-\delta_{1}\right)}{\Delta V_{1} f_{S}} \frac{2\left(\delta_{1}-1\right)}{\delta_{1} R} V_{0}
\end{array}\right\}
$$




$$
\begin{aligned}
& \Delta V_{2}=\frac{\left(1-\delta_{2}\right) T_{S}}{R C_{2}\left(1-\delta_{1}\right)}\left(\frac{\delta_{1} \delta_{2}}{2\left(\delta_{1}-1\right)}-\frac{\delta_{1}^{2}}{2\left(\delta_{1}-1\right)}-\delta_{2}+\frac{\delta_{1}}{2}\right) V_{0} \\
& C_{2}=\frac{\left(1-\delta_{2}\right)}{R \Delta V_{2} f_{S}\left(1-\delta_{1}\right)}\left(\frac{\delta_{1} \delta_{2}}{2\left(\delta_{1}-1\right)}-\frac{\delta_{1}^{2}}{2\left(\delta_{1}-1\right)}-\delta_{2}+\frac{\delta_{1}}{2}\right) V_{0}
\end{aligned}
$$

Output capacitor can be determined from the output voltage ripple.

$$
\begin{aligned}
& \Delta V_{0}=\frac{\Delta i_{L 0} T_{S}}{8 C_{0}} \\
& C_{0}=\frac{\Delta i_{L 0}}{8 \Delta V_{0} f_{S}}
\end{aligned}
$$

The values of the capacitors can be found if the output voltage, source voltages, desired ripples, switching frequency and duty cycle are known. A 5\% current ripples in inductors, 5\% voltage ripples in buffer capacitor $C_{1}$ and $4 \%$ voltage ripples in output capacitor $C_{0}$ have been considered to design the parameters listed in Table 2 . The converter is simulated and various current and voltage waveforms are presented in Figure 9a-j.

Table 2. Components of the proposed converter.

\begin{tabular}{ccccc}
\hline S1.No & Component & Symbol & Simulation & Hardware \\
\hline 1 & Inductors & $\mathrm{L}_{1}$ and $\mathrm{L}_{2}$ & $0.8 \& 1.51 \mathrm{mH}$ & $1 \& 1.5 \mathrm{mH}$ \\
\hline 2 & Capacitors & $\mathrm{C}_{1}$ and $\mathrm{C}_{2}$ & $46.3 \mu \mathrm{F} \& 63 \mu \mathrm{F}$ & $50 \mu \mathrm{F}, 63 \mathrm{~V} \& 72 \mu \mathrm{F}, 50 \mathrm{~V}$ \\
\hline 3 & Output Inductor & $\mathrm{L}_{0}$ & $2 \mathrm{mH}$ & $2 \mathrm{mH}$ \\
\hline 4 & Output Capacitor & $\mathrm{C}_{0}$ & $1.7 \mu \mathrm{F}$ & $2.2 \mu \mathrm{F}, 35 \mathrm{~V}$ \\
\hline 5 & Load Resistance & $\mathrm{R}$ & $5.76 \Omega$ & $6 \Omega$ \\
\hline 6 & Switching Frequency & $\mathrm{f}_{\mathrm{sw}}$ & $20 \mathrm{kHz}$ & $20 \mathrm{kHz}$ \\
\hline
\end{tabular}

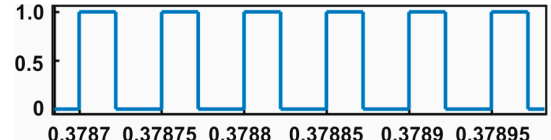

(a)

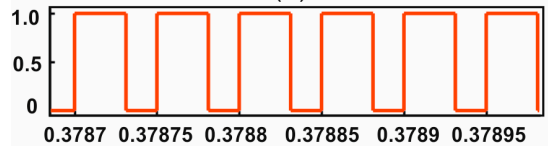

(b)

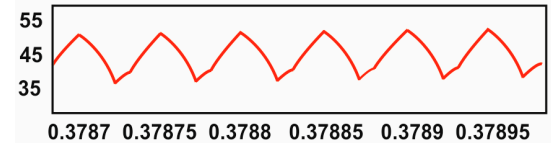

(c)

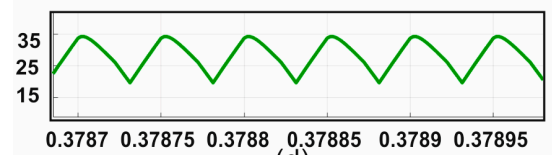

(d)

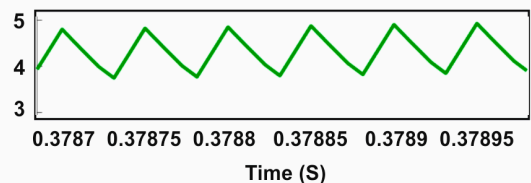

(e)

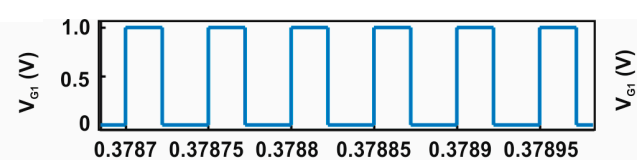

(f)

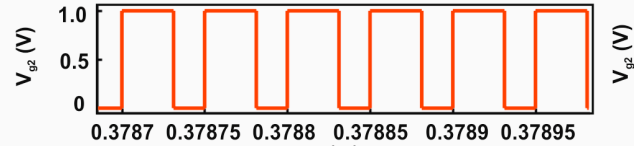

(g)

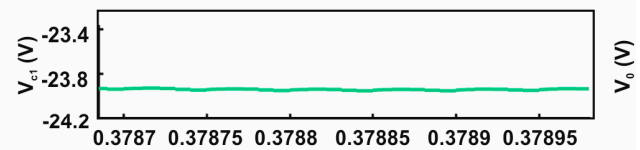

(h)

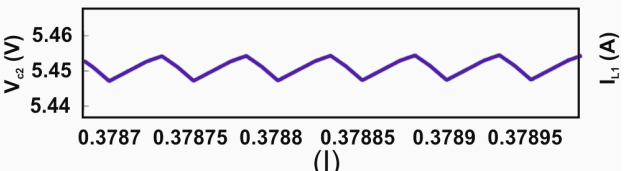

(I)

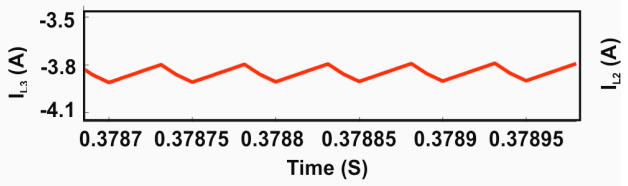

(j)

Figure 9. Waveforms of various voltages and currents during mode $2(\mathbf{a}, \mathbf{f})$ Gate signal to $S_{1},(\mathbf{b}, \mathbf{g})$ Gate signal to $S_{2}$, (c) Voltage across capacitor $C_{1}$, (d) Voltage across capacitor $C_{2}$, (e) Current through the inductor $\mathrm{i}_{3}$, (h) Output voltage (i) Current through the inductor $\mathrm{L}_{1}$, (j) Current through the inductor $\mathrm{L}_{2}$. 


\subsection{Small-Signal Modeling}

Voltage regulation should be maintained in spite of the changes in input and output parameters in any power converter, which necessitates a design of feedback controller. Modeling plays a good role in providing information about the dynamic behavior of the converter and in deriving a feedback control system. Numerous modeling methods have been proposed for power electronic converters. The State-Space Averaging (SSA) method is the most commonly used method to design control loops and to investigate the transient and steady state response of the converter. This modeling method has three steps: (1) writing the state-space equations for all states in a switching cycle; (2) derivation of average state-space equation; and (3) applying perturbations to the averaged equation to derive the linear first order small-signal equations, from which different transfer functions relating the inputs and outputs can be obtained. Then, matrices A and B are formed, which describe the converter model. The derived model fits in the following form (22).

$$
\left.\begin{array}{l}
\dot{X}=A X+B U \\
Y=C X+D U
\end{array}\right\}
$$

where $\mathrm{X}, \mathrm{U}, \mathrm{Y}$ and $\dot{x}=\mathrm{dx} / \mathrm{dt}$ represent the state vector, the input or control vector, the output vector and the derivative of $X$ respectively. Matrices A, B, C and D are the system, control, output and feed-forward matrices respectively. $\mathrm{A}$ and $\mathrm{B}$ are used to extract various transfer functions of the system.

$$
\begin{gathered}
X=\left[\begin{array}{cccccc}
i_{L 1} & i_{L 2} & i_{L 3} & v_{C 1} & v_{C 2} & v_{0}
\end{array}\right]^{T} \\
U=\left[\begin{array}{ll}
V_{1} & V_{2}
\end{array}\right]^{T} \\
Y=\left[V_{0}\right]
\end{gathered}
$$

From the Equation (4) in Section 2 and according to circuit theory, the dynamic equations representing state- 1 can be written as follows

$$
\left.\begin{array}{l}
L_{1} \frac{d i_{L 1}}{d t}=V_{1}, L_{2} \frac{d i_{L 2}}{d t}=V_{2} \\
L_{0} \frac{d i_{L 0}}{d t}=V_{0}-V_{C 1} \\
C_{1} \frac{d v_{C 1}}{d t}+C_{2} \frac{d v_{C 2}}{d t}=i_{L 0} \\
C_{0} \frac{d v_{0}}{d t}=i_{L 0}-i_{0}
\end{array}\right\}
$$

The derived dynamic equations representing state-2 and state-3 are given in (27) and (28) respectively.

$$
\left.\begin{array}{l}
L_{1} \frac{d i_{L 1}}{d t}=V_{1}-V_{C 1}+V_{C 2} \\
L_{2} \frac{d i_{L 2}}{d t}=V_{2}, L_{0} \frac{d i_{L 0}}{d t}=V_{0}-V_{C 2} \\
C_{1} \frac{d v_{C 1}}{d t}=i_{L 1}, C_{2} \frac{d v_{C 2}}{d t}=i_{L 0}-i_{C 1} \\
C_{0} \frac{d v_{0}}{d t}=i_{L 0}-i_{0} \\
L_{1} \frac{d i_{L 1}}{d t}=V_{1}-V_{C 1} \\
L_{2} \frac{d i_{L 2}}{d t}=V_{2}-V_{C 2}, L_{0} \frac{d i_{L 0}}{d t}=V_{0} \\
C_{1} \frac{d v C 1}{d t}=i_{L 1}, C_{2} \frac{d v_{C 2}}{d t}=i_{L 2} \\
C_{0} \frac{d v_{0}}{d t}=i_{L 0}-i_{0}
\end{array}\right\}
$$


The obtained state space model in matrix form is given in (29).

$$
\begin{aligned}
{\left[\begin{array}{c}
\frac{d i_{L 1}}{d t} \\
\frac{d i L_{2}}{d t} \\
\frac{d i_{3}}{d t} \\
\frac{d v_{11}}{d t} \\
\frac{d v_{C 2}}{d t} \\
\frac{d v_{0}}{d t}
\end{array}\right]=} & {\left[\begin{array}{cccccc}
0 & 0 & 0 & \frac{\delta_{1}-1}{L_{1}} & \frac{\left(\delta_{2}-\delta_{1}\right)}{L_{1}} & 0 \\
0 & 0 & 0 & 0 & \frac{-\left(1-\delta_{2}\right)}{L 2} & 0 \\
0 & 0 & 0 & \frac{-\delta_{1}}{L_{0}} & \frac{-\left(\delta_{2}-\delta_{1}\right)}{L_{0}} & \frac{-1}{L_{0}} \\
\frac{1-\delta_{1}}{C_{1}} & 0 & \frac{-\delta_{1}}{2 C_{1}} & 0 & 0 & 0 \\
\frac{-\left(\delta_{2}-\delta_{1}\right)}{C_{2}} & \frac{1-\delta_{2}}{C_{2}} & \frac{\delta_{2}-\delta_{1}}{C_{2}}-\frac{\delta_{1}}{2 C_{2}} & 0 & 0 & 0 \\
0 & 0 & \frac{1}{C_{0}} & 0 & 0 & \frac{-1}{R C_{0}}
\end{array}\right]\left[\begin{array}{l}
i_{L 1} \\
i_{L 2} \\
i_{L 0} \\
v_{C 1} \\
v_{C 2} \\
v_{0}
\end{array}\right]+\left[\begin{array}{ll}
\frac{1}{L_{1}} & 0 \\
0 & \frac{1}{L_{2}} \\
0 & 0 \\
0 & 0 \\
0 & 0 \\
0 & 0
\end{array}\right]\left[\begin{array}{l}
V_{1} \\
V_{2}
\end{array}\right] } \\
& {\left[\begin{array}{l}
V_{0} \\
I_{0}
\end{array}\right]=\left[\begin{array}{llllll}
0 & 0 & 0 & 0 & 0 & 1 \\
0 & 0 & 0 & 0 & 0 & \frac{1}{R}
\end{array}\right]\left[\begin{array}{l}
i_{L 1} \\
i_{L 2} \\
i_{L 0} \\
v_{C 1} \\
V_{C 2} \\
V_{0}
\end{array}\right]+\left[\begin{array}{ll}
0 & 0 \\
0 & 0
\end{array}\right]\left[\begin{array}{l}
V_{1} \\
V_{2}
\end{array}\right] }
\end{aligned}
$$

Using (29) with the obtained model, the transfer functions are derived and shown in (30)-(32).

$$
\begin{gathered}
T=C[S I-A]^{-1} B+D \\
\frac{V_{0}}{V_{1}}=\frac{-8.889 \times 10^{10} s^{2}-9.877 \times 10^{19}}{s^{6}+41.67 s^{5}+9.406 \times 10^{7} s^{4}+3.919 \times 10^{9} s^{3}+2.092 \times 10^{15} s^{2}+8.711 \times 10^{16} s+3.951 \times 10^{19}} \\
\frac{V_{0}}{V_{2}}=\frac{1.333 \times 10^{12} s^{2}-3.556 \times 10^{19}}{s^{6}+41.67 s^{5}+9.406 \times 10^{7} s^{4}+3.919 \times 10^{9} s^{3}+2.092 \times 10^{15} s^{2}+8.711 \times 10^{16} s+3.951 \times 10^{19}}
\end{gathered}
$$

These transfer functions are evaluated using MATLAB commands to eliminate manual mistakes, and the step data analysis is obtained. Figure 10 illustrates the response of the plant to a unit step input.

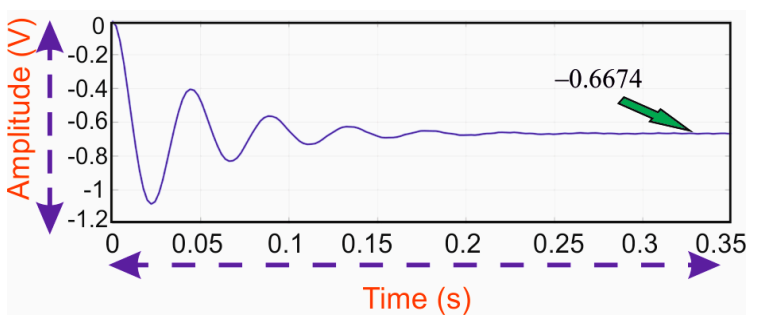

(a)

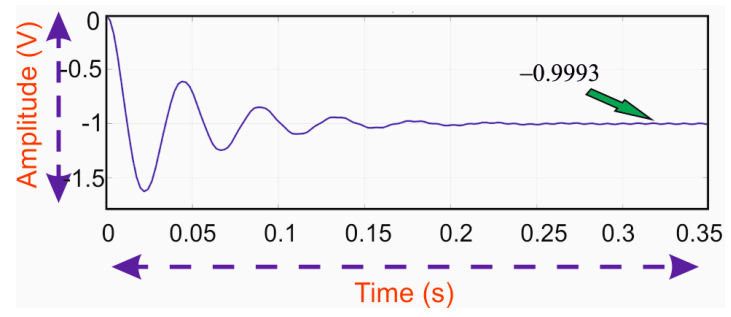

(b)

Figure 10. Step response of open loop system (a) with $V_{1}$ source and (b) with $V_{2}$ source.

Figure 10a,b depicts the step response of the converter with step change in input sources $\mathrm{V}_{1}$ and $V_{2}$ respectively. It is clear that the response is inverted as the Cuk converter has an inverted output. The steady state value settles at -0.6674 in Figure 10a and has an error of $33.26 \%$ with a peak overshoot of $62.7284 \%$. In Figure 10b, the response settles at -0.9993 and has an error of $0.7 \%$ with a peak overshoot of $62.64644 \%$.

\section{Design of Controller}

The most popular proportional plus integral (PI) controller has been designed to eliminate the steady state error pointed in Figure 10. One can obtain the proportional and the integral output as given in (30).

$$
P_{\text {out }}=K_{p} e(t), I_{\text {out }}=K_{i} \int_{0}^{t} e(t) d t
$$


Ziegler-Nichols PI tuning was adopted to obtain the values of the proportional gain $\mathrm{K}_{\mathrm{p}}$ and integral time $T_{i}$. The $S$-shaped waveform can be defined by two parameters, delay time $\mathrm{L}$ and time constant $\mathrm{T}$ as illustrated in Figure 11a.

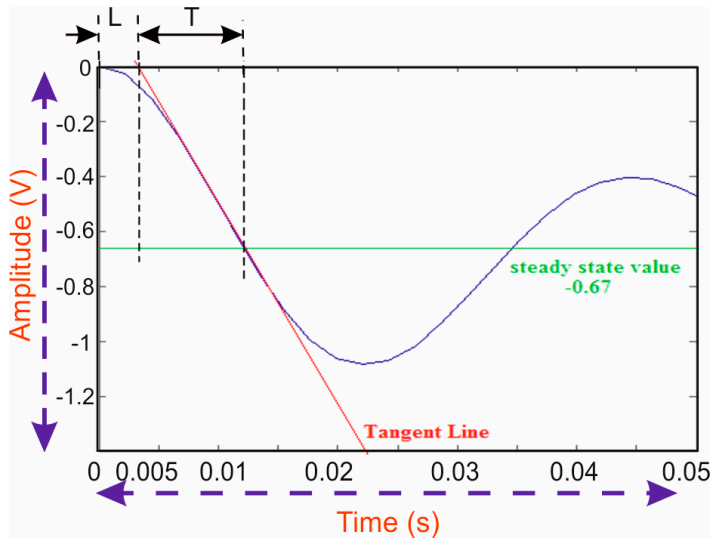

(a)

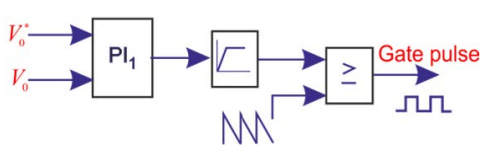

(b)

Figure 11. (a) S shaped curve. (b) Control with PI controller.

The designed PI controller has been incorporated with the plant as shown in Figure 11b. The parameters of the controller can be obtained as given in (34)

$$
\text { PIcontroller } \left.=K_{p}\left(1+\frac{1}{T_{i} S}\right), K_{P}=0.9 \frac{T}{L}, T_{i}=\frac{L}{0.3}\right\}
$$

Figure 12a,b show the step response of the converter with PI controller for the step change in input sources $V_{1}$ and $V_{2}$ respectively. The steady state error is reduced and overshoots of $0.0013 \%$ and $0.0068 \%$ are achieved. To make both sources work effectively, with the magnitude of input voltage $\mathrm{V}_{1}>\mathrm{V}_{2}$, the duty cycle is considered as $\delta_{1}<\delta_{2}$.

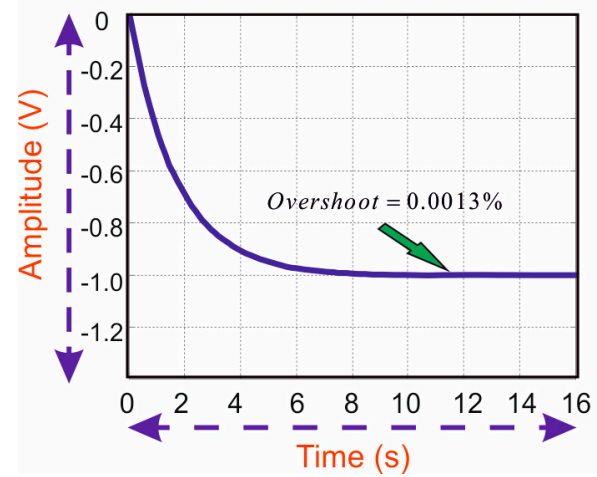

(a)

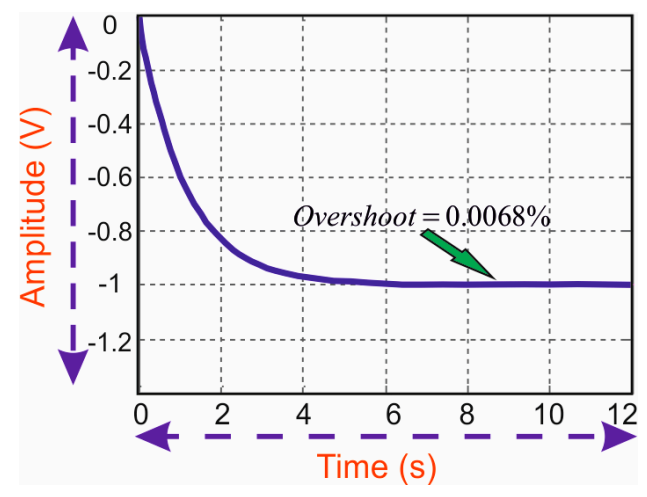

(b)

Figure 12. Step response of the system in closed loop (a) with $V_{1}$ source and (b) with $V_{2}$ source.

\section{Results and Discussion}

A $100 \mathrm{~W}, 20 \mathrm{kHz}$ NI-TPC converter using MOSFET switches was fabricated in the laboratory (Figure 13.) with the designed values. The whole system consists of the developed converter, two DC power sources representing the renewable energy sources such as PV and fuel cell, a FPGA spartan6 controller board, and a resistive load. Triggering signals for the switches and the controller are realized using FPGA Spartan 6 controller board. The specifications of components used are listed in Table 2. 


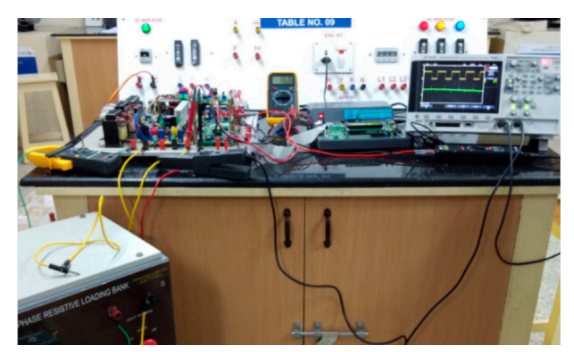

Figure 13. Hardware setup.

Experiments have been conducted using the proposed NI-TPC converter with an $18 \mathrm{~V}$ input voltage. Duty ratios of $60 \%$ and $40 \%$ were chosen for the boost and buck operations respectively. The results are shown in Figures 14 and 15. Also, the test has been performed with $12 \mathrm{~V}$ input voltage and observed that the performance is satisfying the theoretical analysis. However, these results are not provided in this paper.

Figure 14a shows the current through inductors $\mathrm{L}_{1}, \mathrm{~L}_{2}$ and the load current $\mathrm{I}_{0}$ along with gate signal applied under boost operation. It can be seen that the current ripples of inductors $\Delta \mathrm{i}_{\mathrm{L} 1}, \Delta \mathrm{i}_{\mathrm{L} 2}$ and load current $\Delta \mathrm{i}_{0}$ are in between $(5.9 \mathrm{~A}, 5.3 \mathrm{~A}),(4.3 \mathrm{~A}, 3.4 \mathrm{~A})$ and $(4.2 \mathrm{~A}, 3.4 \mathrm{~A})$ respectively. The average values and ripples are in close approximation with the $5.55 \mathrm{~A}, 3.71 \mathrm{~A}$, and 3.6 A calculated from (2) and (3). The voltage across the capacitors $C_{1}$ and $C_{2}$ along with gate signal are shown in Figure $14 \mathrm{~b}$. From Figure $14 \mathrm{~b}$, the average voltages across the capacitors are $44 \mathrm{~V}$ and $-26.2 \mathrm{~V}$ which are in agreement with the theoretical calculations from (1) and (2). The generated gate signal and source and output voltages are $15 \mathrm{~V}, 18 \mathrm{~V}$, and $-26.2 \mathrm{~V}$, respectively, as shown in Figure 14c.

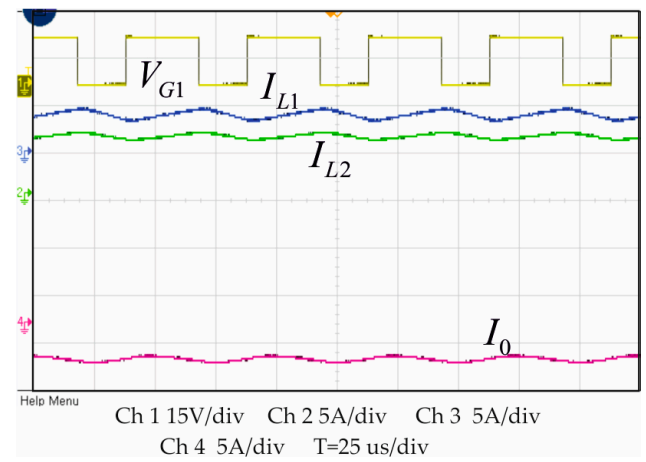

(a)

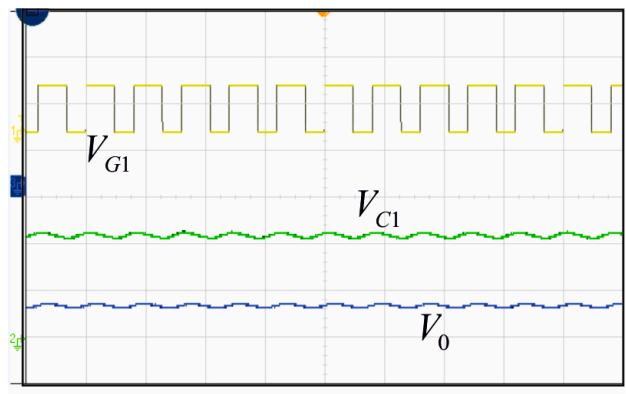

Ch 1 15V/div Ch 2 20V/div Ch 3 10V/div T=62.5 us/div

(b)

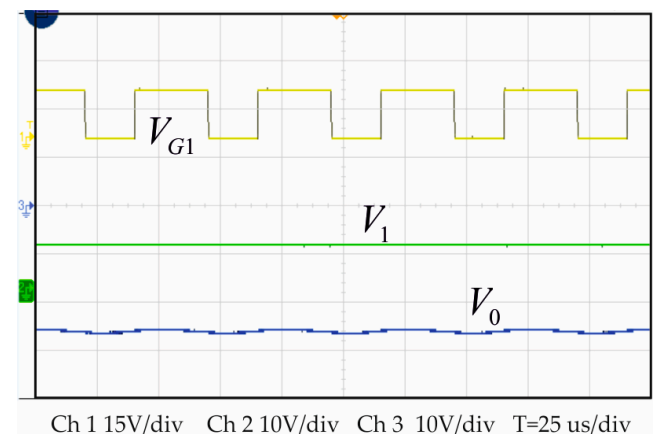

(c)

Figure 14. Various voltage and current measurements from experiments during Mode 1 with source 1 (Boost mode): (a) Gate signal, inductor currents through $\mathrm{L}_{1}, \mathrm{~L}_{2}$ and Load current (CH 1-4); (b) Gate signal and capacitor voltages across $\mathrm{C}_{1}$ and $\mathrm{C}_{2}(\mathrm{CH} 1-3)$; (c) Gate signal, source voltages and output voltage (CH 1-3). 


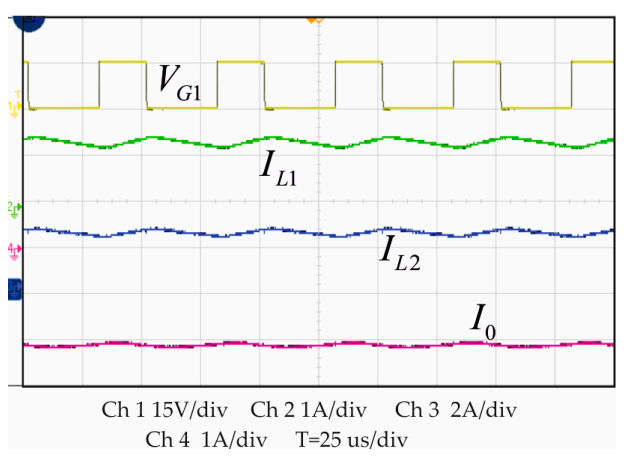

(a)

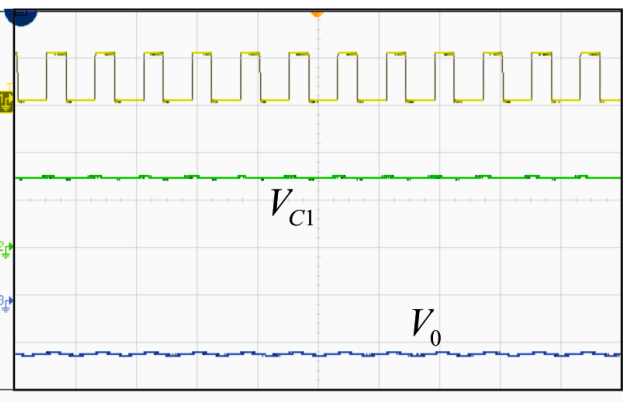

Ch 1 15V/div Ch 20V/div Ch 3 10V/div T=62.5 us/div

(b)

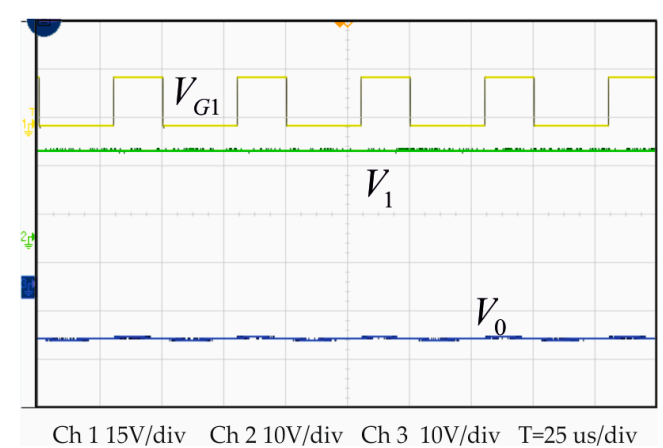

(c)

Figure 15. Various voltage and current measurements from experiments during Mode 1 with source 1 (Buck mode): (a) Gate signal, inductor currents through $\mathrm{L}_{1}, \mathrm{~L}_{2}$ and load current (CH 1-4); (b) Gate signal and capacitor voltages across $\mathrm{C}_{1}$ and $\mathrm{C}_{2}(\mathrm{CH} 1-3)$; (c) Gate signal, source voltages and output voltage (CH 1-3).

Figure 15a shows the current through the inductors $\mathrm{L}_{1}, \mathrm{~L}_{2}$ and load current $1.4 \mathrm{~A}, 2.2 \mathrm{~A}$ and $2.17 \mathrm{~A}$, under step down mode, which are closer to $1.39 \mathrm{~A}, 2.08 \mathrm{~A}$, and $2.08 \mathrm{~A}$ calculated from (2) and (3). The corresponding ripples $\Delta \mathrm{i}_{\mathrm{L} 1}, \Delta \mathrm{i}_{\mathrm{L} 2}$ and $\Delta \mathrm{i}_{0}$ are within $(1.55,1.25 \mathrm{~A}),(2.4$ and $2.0 \mathrm{~A})$ and $(2.3$ and $2.1 \mathrm{~A})$ respectively. It is found that the ripples are slightly more than the designed value of $5 \%$. The voltage ripples of the capacitor are shown in Figure 15b. It can be seen that the ripples of capacitors are within $(28.8,29.55 \mathrm{~V})$ for $\mathrm{C}_{1}$ and $(11.0$ to $11.4 \mathrm{~V})$ for $\mathrm{C}_{2}$. The gate signal, source and output voltages are $15 \mathrm{~V}, 18 \mathrm{~V}$ and $-11.2 \mathrm{~V}$ respectively, as shown in Figure $15 \mathrm{c}$.

The performance of the converter was tested in DISO mode and the corresponding voltage and current signals are shown in Figure 16. The current through the inductors $\mathrm{L}_{1}$ and $\mathrm{L}_{3}$ with gate signal applied to both the switches are shown in Figure 16a. The inductor currents $\mathrm{i}_{\mathrm{L} 2}$ and $\mathrm{i}_{0}$ are shown in Figure 16b. It can be observed that the average inductor currents are matching with results from (3), (14) and (15) and ripples are slightly more than the designed value of $5 \%$. The voltage across the capacitors $C_{1}$ and $C_{2}$ are $40 \mathrm{~V}$ and $34 \mathrm{~V}$ respectively as shown in Figure 16c. It can be seen that the ripples of capacitors are within $(36.5 \mathrm{~V}, 44.5 \mathrm{~V})$ for $\mathrm{C}_{1}$ and $(31.5$ to $39 \mathrm{~V})$ for $\mathrm{C}_{2}$. The obtained voltage ripples (approximately 10\%) are more than the designed value (5\%). However, it can be observed that the current of all the ports, $\mathrm{I}_{\mathrm{L} 1}, \mathrm{I}_{\mathrm{L} 2}$ and $\mathrm{I}_{0}$ are continuous with less ripples.

The response of the converter during transient load condition is shown in Figure 17. The load is varied to increase the load current from $0.6 \mathrm{~A}$ to $3.8 \mathrm{~A}$. Approximately $20 \mathrm{~s}$ later, the load decreased to $0.8 \mathrm{~A}$ from $3.8 \mathrm{~A}$. In both the cases, it is observed that the load voltage is regulated at $23.9 \mathrm{~V}$ which is closer to the desired value of $24 \mathrm{~V}$. The load voltage magnitude is shown positive by using the probe with opposite polarity. 


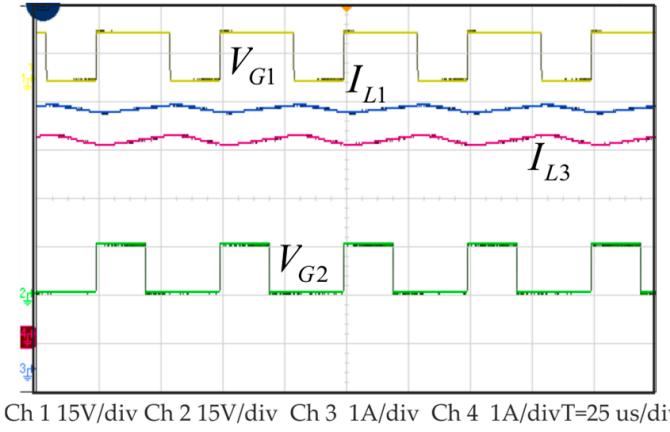

(a)

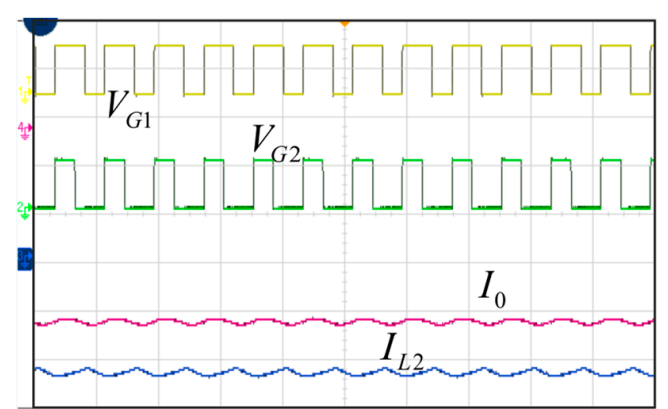

Ch 1 15V/div Ch 2 15V/div Ch 3 2A/div Ch 4 2A/div T=65 us/div

(b)

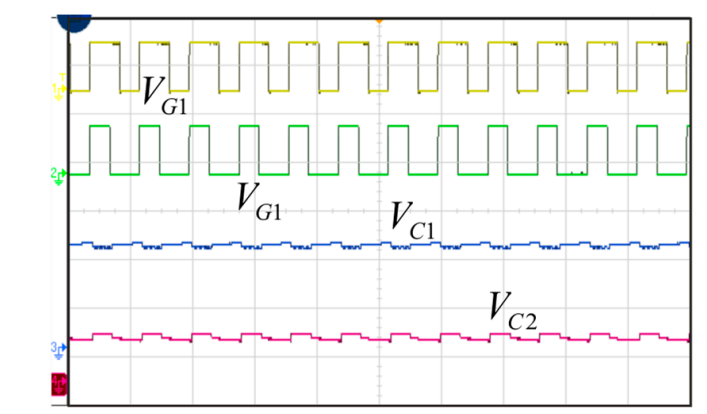

Ch 1 15V/div Ch $215 \mathrm{~V} /$ div Ch 3 20V/div Ch 4 40V/div T=65 us/div

(c)

Figure 16. Various voltage and current measurements from experiments during Mode 2 with both sources: (a) Gate pulses of both switches and inductor currents through $\mathrm{L}_{1}$ and $\mathrm{L}_{3}(\mathrm{CH} 1-4)$; (b) Gate pulses of switches, inductor currents through $\mathrm{L}_{2}$ and $\mathrm{L}_{0}(\mathrm{CH} 1-4)$; (c) Gate signals of $\mathrm{S}_{1}$ and $\mathrm{S}_{2}$, and capacitor voltages across $\mathrm{C}_{1}$ and $\mathrm{C}_{2}(\mathrm{CH} 1-4)$.

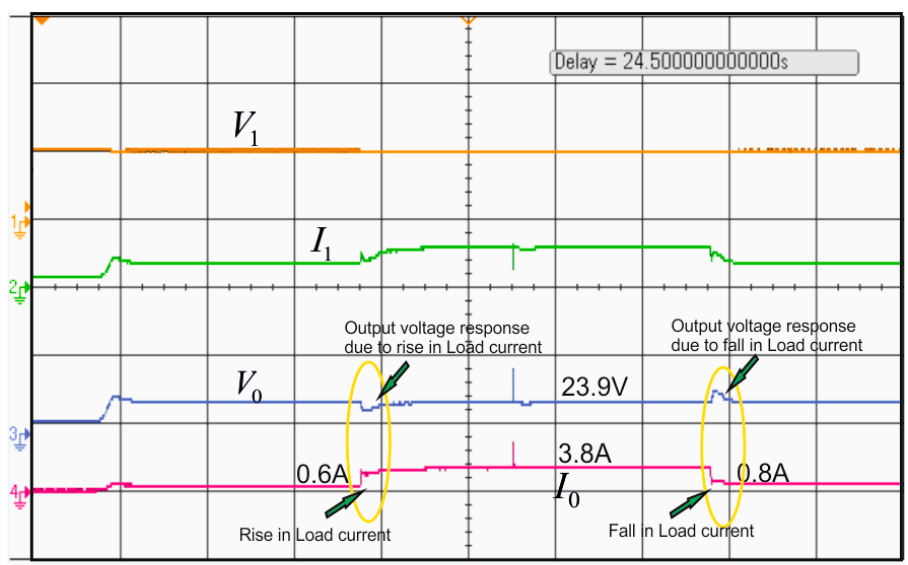

Ch 1 15V/div Ch 2 10A/div Ch 3 50V/div Ch 4 10A/div T=5 s/div

Figure 17. Voltages and currents from the experiment during transient condition. Input voltage, input current, load voltage and current ( $\mathrm{CH} 1-4)$.

Figure 18a,b present the comparison plot between the theoretical, simulation and experimental absolute values of voltage gains as a function of duty ratio for SISO and DISO modes, respectively. It is obvious that both the theoretical and experimental voltage gains are increasing as the duty ratio increases. In addition, the voltage gain obtained from the experiment closely approximates the theoretical and the simulation results between 0.3 and 0.5 , whereas a slight deviation has been observed in the duty ratio beyond 0.5 with increasing voltage difference. It is worth mentioning that this difference is due to the component losses. 


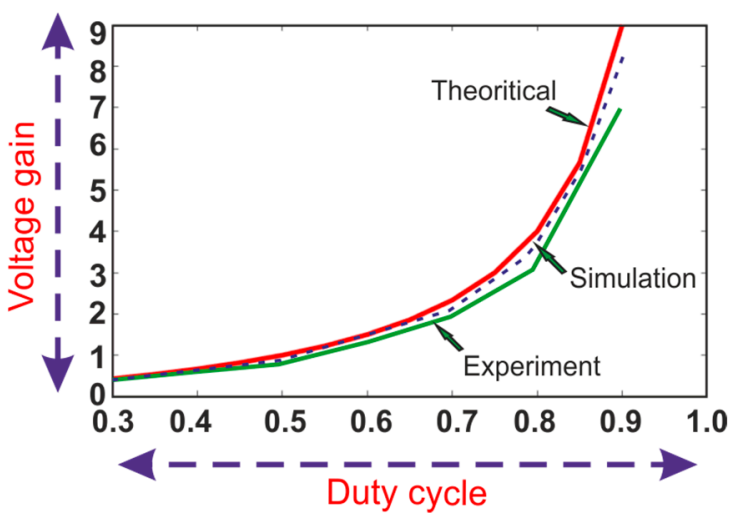

(a)

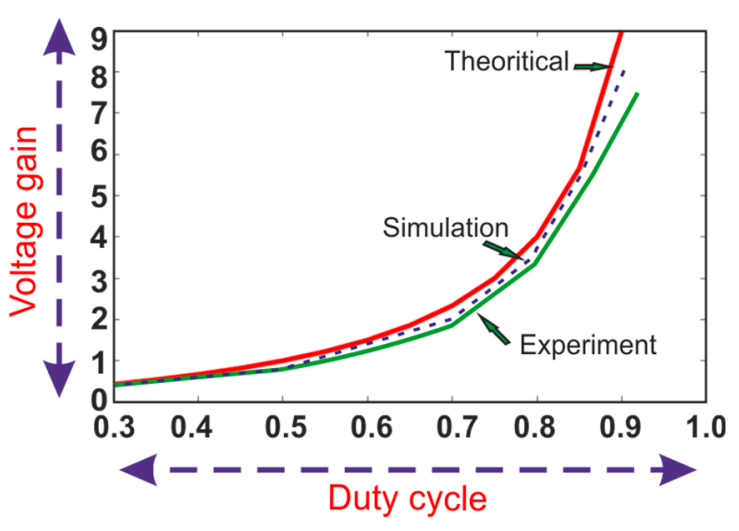

(b)

Figure 18. Voltage gain as a function of duty cycle (a) SISO mode (b) DISO mode.

Thus, the results validate the theoretical analysis and show the good feasibility of expected operation. Several tests are conducted and the maximum efficiency between the modes has been compared and plotted in a graph as shown in Figure 19, and the observed efficiencies for Mode 1 (SISO) with $\mathrm{V}_{1}$ and $\mathrm{V}_{2}$ sources are $92.74 \%$ and $91.15 \%$ respectively, and for Mode 2 is $90.43 \%$. Comparing with efficiencies obtained through simulation, efficiencies for Mode 1 (SISO) with individual contribution of $\mathrm{V}_{1}$ and $\mathrm{V}_{2}$ sources are $94.13 \%$ and $93.66 \%$, respectively, and for Mode 2 is $92.21 \%$. Table 3 presents the comparison of various TP-NI converters with the proposed one. It is clear that the proposed converter provides continuous current at all the ports with a reduction in components.

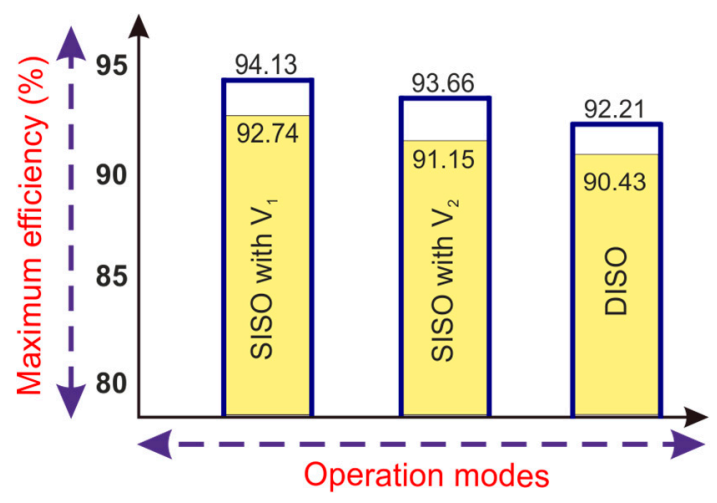

Figure 19. Maximum efficiency for various modes.

Table 3. Comparison of converters.

\begin{tabular}{ccccccc}
\hline Circuit Elements & {$[5]$} & {$[10]$} & {$[22]$} & {$[30]$} & [31] & $\begin{array}{c}\text { The Proposed } \\
\text { Converter }\end{array}$ \\
\hline Topology & Nonisolated & Nonisolated & Nonisolated & Nonisolated & Nonisolated & Nonisolated \\
Inductors & 2 & 3 & 2 & 2 & 2 coupled & 3 \\
Capacitors & 3 & 4 & 3 & 1 & 3 & 3 \\
Active switches & 4 & 3 & 3 & 4 & 5 & 2 \\
Diodes & 2 & 1 & 4 & 2 & Nil & 1 \\
Common ground & Yes & Yes & Yes & Yes & Yes & Yes \\
Continuous current at & No & Yes & No & No & No & Yes \\
all the ports & $400 \mathrm{~W}$ & $1.2 \mathrm{~kW}$ & $200 \mathrm{~W}$ & $1 \mathrm{~kW}$ & $200 \mathrm{~W}$ & $100 \mathrm{~W}$ \\
Prototype rating & $100 \mathrm{kHz}$ & $100 \mathrm{kHz}$ & $40 \mathrm{kHz}$ & $20 \mathrm{kHz}$ & $50 \mathrm{kHz}$ & $20 \mathrm{kHz}$ \\
Switching frequency & $96 \%$ & $93.5 \%$ & $92.7 \%$ & $95.5 \%$ & $90.1 \%$ & $94.13 \%$ \\
Maximum efficiency & 96 & & &
\end{tabular}




\section{Conclusions}

In this paper a NI-TPC converter is synthesized using conventional Cuk converters to interface RS like Fuel cell and PV source. The operational modes and analysis of the converter are discussed in detail. Fewer active and passive components and a shared output inductor are the advantages of this converter. The continuous input and output currents are achieved owing to the presence of inductors. Therefore, this converter is appropriate for FC power supplies that necessitates continuous current with low ripple. The simulation and experimental results are provided to verify the feasibility of the proposed converter.

Author Contributions: Formal Analysis, B.C.; Investigation, B.C.; Methodology, B.C.; Resources, C.N.; Supervision, C.N.; Validation, C.N.; Writing-Original Draft, B.C.; Writing-Review \& Editing, B.C., C.N., and S.S.D.

Funding: This research received no external funding.

Acknowledgments: The authors would like to thank SRM IST, Kattankulathur, India for the financial support in executing this work successfully. This work has been carried out as a part of research work in the Department of Electrical and Electronics Engineering, SRM IST, Kattankulathur, India.

Conflicts of Interest: The authors declare no conflicts of interest.

\section{References}

1. Wang, J.; Dunford, W.G.; Mauch, K. Synthesis of two-inductor DC-DC converters. In Proceedings of the Power Electronics Specialists Conference, Saint Louis, MO, USA, 27 June 1997; pp. 1367-1373.

2. Landsman, E.E. A unifying derivation of switching DC-DC converter topologies. In Proceedings of the IEEE Power Plectronics Ppecialists Ponference, San Diego, CA, USA, 18-22 June 1979; pp. 18-22.

3. Khaligh, A.; Cao, J.; Lee, Y.-J. A multiple-input DC-DC converter topology. IEEE Trans. Power Electron. 2009, 24, 862-868. [CrossRef]

4. Kumar, L.; Jain, S. Multiple-input DC/DC converter topology for hybrid energy system. IET Power Electron. 2013, 6, 1483-1501. [CrossRef]

5. Zhou, Z.; Wu, H.; Ma, X.; Xing, Y. A non-isolated three-port converter for stand-alone renewable power system. In Proceedings of the IECON 2012-38th Annual Conference on IEEE Industrial Electronics Society, Montreal, QC, Canada, 25-28 October 2012; pp. 3352-3357.

6. Wang, C.-S.; Li, W.; Wang, Y.-F.; Han, F.-Q.; Meng, Z.; Li, G.-D. An isolated three-port bidirectional DC-DC converter with enlarged ZVS region for HESS applications in DC microgrids. Energies 2017, 10, 446. [CrossRef]

7. Reddi, N.K.; Ramteke, M.R.; Suryawanshi, H.M. Dual-Input Single-Output Isolated Resonant Converter with Zero Voltage Switching. Electronics 2018, 7, 96. [CrossRef]

8. Wu, Y.-E.; Chiu, P.-N. A High-Efficiency Isolated-Type Three-Port Bidirectional DC/DC Converter for Photovoltaic Systems. Energies 2017, 10, 434. [CrossRef]

9. De Morais, J.L.S.; Gules, R. Three-port converter based on the bidirectional Cuk and the LC series-resonant half-bridge topologies for renewable energy applications. In Proceedings of the Industry Applications (INDUSCON), Curitiba, Brazil, 20-23 November 2016; pp. 1-8.

10. Zhu, H.; Zhang, D.; Zhang, B.; Zhou, Z. A nonisolated three-port dc-dc converter and three-domain control method for PV-battery power systems. IEEE Trans. Ind. Electron. 2015, 62, 4937-4947. [CrossRef]

11. Georgious, R.; Garcia, J.; Garcia, P.; Navarro-Rodriguez, A. A Comparison of Non-Isolated High-Gain Three-Port Converters for Hybrid Energy Storage Systems. Energies 2018, 11, 658. [CrossRef]

12. Fong, Y.; Cheng, K.; Raman, S.R.; Wang, X. Multi-Port Zero-Current Switching Switched-Capacitor Converters for Battery Management Applications. Energies 2018, 11, 1934. [CrossRef]

13. Chen, Y.-M.; Liu, Y.-C.; Wu, F.-Y. Multi-input DC/DC converter based on the multiwinding transformer for renewable energy applications. IEEE Trans. Ind. Electron. 2002, 38, 1096-1104.

14. Kwasinski, A. Identification of feasible topologies for multiple-input DC-DC converters. IEEE Trans. Ind. Electron. 2009, 24, 856-861. [CrossRef]

15. Liu, Y.C.; Chen, Y.-M. A systematic approach to synthesizing multi-input DC-DC converters. IEEE Trans. Ind. Electron. 2009, 24, 116-127. 
16. Wu, H.; Xing, Y.; Xia, Y.; Sun, K. A family of non-isolated three-port converters for stand-alone renewable power system. In Proceedings of the IECON 2011-37th Annual Conference on IEEE Industrial Electronics Society, Melbourne, Australia, 7-10 November 2011; pp. 1030-1035.

17. Wu, H.; Zhang, J.; Xing, Y. A family of multiport buck-boost converters based on DC-link-inductors (DLIs). IEEE Trans. Ind. Electron. 2015, 30, 735-746.

18. Cheng, T.; Lu, D.D.-C.; Qin, L. Non-Isolated Single-Inductor DC/DC Converter with Fully Reconfigurable Structure for Renewable Energy Applications. IEEE Trans. Circuits Syst. Express Briefs 2018, 65, 351-355. [CrossRef]

19. Zhao, J.; Iu, H.H.C.; Fernando, T.; An, L.; Lu, D.D.-C. Design of a non-isolated single-switch three-port DC-DC converter for standalone PV-battery power system. In Proceedings of the 2015 IEEE International Symposium on Circuits and Systems (ISCAS), Lisbon, Portugal, 24-27 May 2015; pp. 2493-2496.

20. Cuk, S. A new zero-ripple switching DC-to-DC converter and integrated magnetics. IEEE Trans. Magn. 1983, 19, 57-75. [CrossRef]

21. Almalaq, Y.; Matin, M. Three topologies of a non-isolated high gain switched-inductor switched-capacitor step-up cuk converter for renewable energy applications. Electronics 2018, 7, 94. [CrossRef]

22. Kumar, M.; Babu, Y.N.; Pullaguram, D.; Mishra, S. A high voltage gain non-isolated modified three-port DC/DC converter based on integrated Boost-Cuk topology. In Proceedings of the Asia-Pacific Power and Energy Engineering Conference (APPEEC), Bangalore, India, 8-10 November 2017; pp. 1-6.

23. Biswas, S.; Dhople, S.; Mohan, N. A three-port bidirectional dc-dc converter with zero-ripple terminal currents for pv/microgrid applications. In Proceedings of the IECON 2013-39th Annual Conference of the IEEE Industrial Electronics Society, Vienna, Austria, 10-13 November 2013; pp. 340-345.

24. Biswas, S.; Dhople, S.; Mohan, N. Zero-ripple analysis methods for three-port bidirectional integrated magnetic Ćuk converters. In Proceedings of the IECON 2014-40th Annual Conference of the IEEE Industrial Electronics Society, Dallas, TX, USA, 29 October-1 November 2014; pp. 1889-1895.

25. Ferrera, M.B.; Litran, S.P.; Aranda, E.D.; Marquez, J.M.A. A converter for bipolar DC link based on SEPIC-Cuk combination. IEEE Trans. Power Electron. 2015, 30, 6483-6487. [CrossRef]

26. Chen, Y.; Zhang, P.; Zou, X.; Kang, Y. Dynamical modeling of the non-isolated single-inductor three-port converter. In Proceedings of the Applied Power Electronics Conference and Exposition (APEC), Fort Worth, TX, USA, 16-20 March 2014; pp. 2067-2073.

27. Sato, Y.; Nagata, H.; Uno, M. Non-isolated multi-port converter integrating PWM and phase-shift converters. In Proceedings of the Region. 10 Conference, Penang, Malaysia, 5-8 November 2017; pp. 1097-1102.

28. Yang, H.; Chao, K.; Sun, X.; An, S.; Ren, B.; Zhang, Q. Analysis, modeling and control of a non-isolated four-port dc-dc converter for independent photovoltaic power generation system. In Proceedings of the IECON 2017-43rd Annual Conference of the IEEE Industrial Electronics Society, Beijing, China, 29 October-1 November 2017; pp. 7731-7735.

29. Balaji, C.; Dash, S.S.; Hari, N.; Babu, P.C. A four port non-isolated multi input single output DC-DC converter fed induction motor. In Proceedings of the 2017 IEEE 6th International Conference on Renewable Energy Research and Applications (ICRERA), San Diego, CA, USA, 5-8 November 2017; pp. 631-637.

30. Akar, F.; Tavlasoglu, Y.; Ugur, E.; Vural, B.; Aksoy, I. A bidirectional nonisolated multi-input DC-DC converter for hybrid energy storage systems in electric vehicles. IEEE Trans. Veh. Technol. 2016, 65, 7944-7955. [CrossRef]

31. Chen, Y.-M.; Huang, A.Q.; Yu, X. A high step-up three-port DC-DC converter for stand-alone PV/battery power systems. IEEE Trans. Power Electron. 2013, 28, 5049-5062. [CrossRef]

(C) 2019 by the authors. Licensee MDPI, Basel, Switzerland. This article is an open access article distributed under the terms and conditions of the Creative Commons Attribution (CC BY) license (http://creativecommons.org/licenses/by/4.0/). 